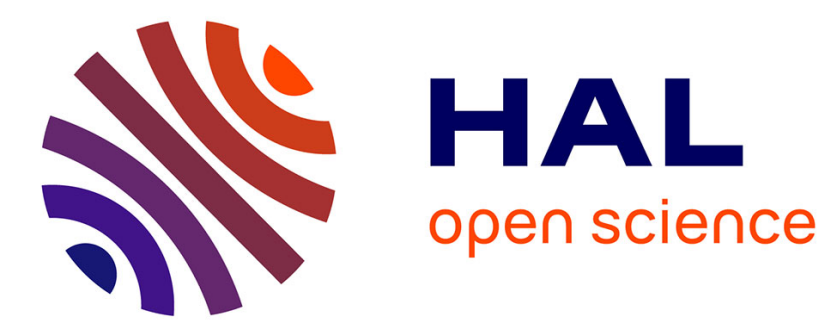

\title{
Traffic-related air pollution. A pilot exposure assessment in Beirut, Lebanon
}

Mireille Borgie, Anne Garat, Fabrice Cazier, Agnes Delbende, Delphine

Allorge, Frederic Ledoux, Dominique Courcot, Pirouz Shirali, Zeina Dagher

\section{- To cite this version:}

Mireille Borgie, Anne Garat, Fabrice Cazier, Agnes Delbende, Delphine Allorge, et al.. Traffic-related air pollution. A pilot exposure assessment in Beirut, Lebanon. Chemosphere, 2013, pp.122-128. hal-00914713

\section{HAL Id: hal-00914713 \\ https://hal-confremo.archives-ouvertes.fr/hal-00914713}

Submitted on 25 Jan 2014

HAL is a multi-disciplinary open access archive for the deposit and dissemination of scientific research documents, whether they are published or not. The documents may come from teaching and research institutions in France or abroad, or from public or private research centers.
L'archive ouverte pluridisciplinaire HAL, est destinée au dépôt et à la diffusion de documents scientifiques de niveau recherche, publiés ou non, émanant des établissements d'enseignement et de recherche français ou étrangers, des laboratoires publics ou privés. 
17

18

19

20

21

22

\section{6}

\section{TRAFFIC-RELATED AIR POLLUTION. A PILOT EXPOSURE}

\section{ASSESSMENT IN BEIRUT, LEBANON}

Mireille BORGIE ${ }^{\mathrm{a}, \mathrm{d}}$, Anne GARAT ${ }^{\mathrm{c}, \mathrm{d}}$, Fabrice CAZIER $^{\mathrm{b}, \mathrm{d}}$, $_{\text {Agnes DELBENDE }}^{\mathrm{b}, \mathrm{d}}$, Camille RICHEVAL ${ }^{\mathrm{c}, \mathrm{d}}$, Delphine ALLORGE ${ }^{\mathrm{c}, \mathrm{d}}$, Frederic LEDOUX $^{\mathrm{a}, \mathrm{d}}$, Dominique COURCOT $^{\mathrm{a}, \mathrm{d}}$, Pirouz SHIRALI ${ }^{\mathrm{a}, \mathrm{d}}$, Zeina DAGHER $^{\mathrm{e}, \mathrm{f}}$

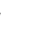

${ }^{\mathrm{a}}$ Unit of Environmental Chemistry and Interactions on Living, EA 4492, University of (1) ${ }^{\mathrm{b}}$ Common Center of Measurements, ULCO, Dunkerque, France Littoral-Côte d'Opale (ULCO), Dunkerque, France ${ }^{\mathrm{c}}$ EA 4483, Faculty of Medicine of Lille, University of Lille North of France, Lille, France ${ }^{\mathrm{d}}$ University of Lille North of France, Lille, France ${ }^{\mathrm{e}}$ Bioactive Molecules Research Group, Doctoral School of Sciences and Technologies, Lebanese University, Lebanon ${ }^{\mathrm{f}}$ Department of Biology, Faculty of Sciences, Lebanese University, Lebanon

8 Corresponding Author: Dr Zeina DAGHER, Bioactive Molecules Research Group, 9 Doctoral School of Sciences and Technologies; Department of Biology, Faculty of Sciences, 20 Lebanese University, P.O. Box 90656, Lebanon. Tel +961 (1) 686 981, fax +961 (1) 680250 , 2 email: dagher_z@ul.edu.lb 


\section{Abstract}

24

25

26

27

Traffic-related volatile organic compounds (VOCs) pollution has frequently been demonstrated to be a serious problem in the developing countries. Benzene and 1,3-butadiene (BD) have been classified as a human carcinogen based on evidence for an increased genotoxic and epigenotoxic effects in both occupational exposure assessment and in vivo/in vitro studies. We have undertaken a biomonitoring of 25 traffic policemen and 23 office policemen in Beirut, through personal air monitoring, assessed by diffusive samplers, as well as through the use of biomarkers of exposure to benzene and BD. Personal benzene, toluene, ethylbenzene, and xylene (BTEX) exposure were quantified by GC-MS/MS, urinary trans, trans-muconic acid ( $t, t$-MA) by HPLC/UV, S-phenyl mercapturic acid (S-PMA), monohydroxy-butenyl mercapturic acid (MHBMA) and dihydroxybutyl mercapturic acid (DHBMA) by ultra-performance liquid chromatography-electrospray tandem mass spectrometry (UPLC/ESI(-)-MS/MS) in MRM (Multiple Reaction Monitoring) mode. We found that individual exposure to benzene in the traffic policemen was higher than that measured in traffic policemen in Prague, in Bologna, in Ioannina and in Bangkok. $t, t$-MA levels could distinguish between office and traffic policemen and showed a better correlation with personal BTEX compounds exposure. However, median MHBMA levels in traffic policemen were slightly elevated, though not significantly higher than in office policemen. Alternatively, DHBMA concentrations could significantly distinguish between office and traffic policemen and showed a better correlation with personal total BTEX exposure. DHMBA, measured in the post-shift urine samples, correlated with both pre-shift MHMBA and pre-shift DHMBA. Moreover, there was not a marked effect of smoking habits on DHBMA. Taken together, these findings suggested that DHBMA is more suitable than MHBMA as biomarker of exposure to BD in humans. Traffic policemen, who are exposed to 
47 benzene and $\mathrm{BD}$ at the roadside in central Beirut, are potentially at a higher risk for 48 development of diseases such as cancer than office policemen.

49

50 Keywords: Biomarkers; benzene; 1,3-butadiene; occupational exposure; traffic-related air 51 pollution

52 


\section{1. INTRODUCTION}

54

55

56

57

59

60

61

62

63

64

65

66

67

68

69

70

71

72

73

74

75

76

77

Traffic-related volatile organic compounds (VOCs) pollution has frequently been demonstrated to be a more serious problem in the developing countries than in the United States and Europe, as indicated by the VOC data obtained in Thailand, India, Pakistan and Egypt (Arayasiri et al., 2010; Rekhadevi et al., 2010; Kamal et al., 2012; Ibrahim et al., 2012). In Beirut, capital of Lebanon, air pollutant concentrations currently exceed air quality standards and guidelines (Waked and Afif, 2012). About $67 \%$ of non methanic VOC emissions are calculated to originate from the on-road transport sector and the majority of vehicles operate on gasoline (Waked and Afif, 2012).

Since concentrations of VOCs are elevated, albeit to different extents, on and near roadways, the individuals whose job requires that they spend long periods of time near vehicles may incur substantial occupational exposures to traffic-related air pollution (Knibbs and Morawska et al., 2012). It is well known that exposure data from stationary monitoring sites cannot give the real exposure profile in urban areas, since the level of traffic VOCs decreases drastically as the distance from the main traffic roads increases (Han and Naeher, 2006). More and until now, no studies have been conducted to assess of the human health risks from urban air pollution exposure in Beirut. Taken together, we carried out a personal exposure measurement campaign among traffic policemen to benzene and 1,3-butadiene (BD), since both compounds are generated from the incomplete combustion of gasoline.

Benzene and BD have been classified as Group 1 carcinogens (IARC; 2008, 2009) based on evidence for an increased genotoxic and epigenotoxic effects in both occupational exposure assessment (Ruchirawat et al., 2010; Carugno et al., 2012; Peluso et al., 2012; Seow et al., 2012; Xiang et al., 2012) and in in vivo and in vitro studies (Dagher et al., 2006; Billet et al., 2010; Koturbash et al., 2011; Sangaraju et al., 2012; Tabish et al., 2012; Abbas et al., 2013). 
Biomarkers of benzene, as urinary trans, trans-muconic acid (t,t-MA) and urinary S-

79 phenylmercapturic acid (S-PMA), have been measured mostly in fuel-related exposure such

80 as in station attendants, in public transportation or in traffic policemen (Fustinoni et al., 2005;

81 Barbieri et al., 2008; Manini et al., 2010), while only a few studies of traffic-related 82 exposures to BD have been performed (Sapkota et al., 2006; Arayasiri et al., 2010).

Although, BD is a known human carcinogen emitted from mobile sources, little is

84 known about traffic-related human exposure to this toxicant. BD is metabolized in vivo to reactive epoxides which are supposedly responsible for the observed carcinogenic effects

86 (category 1A; EU-RAR 2002). A main metabolic pathway for these epoxides is the reaction 87 with glutathione, leading to a urinary excretion of 3,4-dihydroxybutyl mercapturic acid and 388 monohydroxybutenyl mercapturic acids (DHBMA and MHBMA). Up to now, DHBMA and 89 MHBMA have already been used in population surveys as a biomarker of exposure to BD 90 (Arayasiri et al., 2010; Ruchirawat et al., 2010; Cheng et al., 2012).

Hence, it will be of great interest to conduct a biomonitoring pilot study in order to 92 assess traffic-related VOCs in central Beirut, and to evaluate the use of biomarkers of 93 benzene and BD exposure of urban traffic policemen. This work was, therefore, undertaken 94 to determine $t, t$-MA, SPMA, MHBMA and DHBMA in urine spot samples before and at the 95 end of a working shift, and personal air monitoring to airborne benzene, toluene, 96 ethylbenzene, and xylene (BTEX) during the work shift. The influence of personal exposure, 97 job activity and personal characteristics on biomarkers excretion was evaluated. 


\section{MAterials AND Methods}

100

101

102

103

104

105

106

107

108

109

110

111

112

113

114

115

116 Individual air samples were attached to the clothing in the breathing zone of study subjects

117

118

119

120

121

122

123

\subsection{Measurements campaign design}

The campaign took place during May-June 2011 and included measurements of BTEX personal exposure to 47 healthy volunteers. All participants were males. The volunteers group includes 24 traffic policemen and 23 office policemen which constitute the control group. The traffic policemen group consisted of officers whose activity consists exclusively of traffic regulation at intersections of central roads in the city. All participants were carrying passive samplers for BTEX during the working hours.

All participants kept a questionnaire requesting information about lifestyle and health status and a personal daily questionnaire, where they referred to the duration of the performed activities during sampling time.

\subsection{Sample collection}

The sampling was conducted on Monday, which is the first day of the work week after a two days holiday over the weekend to minimize residual exposure from the previous week. The work shift was $7 \mathrm{~h} / \mathrm{d}$ and $5 \mathrm{~h} / \mathrm{d}$ for traffic and office policemen, respectively. and throughout the entire work shift. After air sampling was completed, samples were capped, transported to the laboratory, and stored at $4{ }^{\circ} \mathrm{C}$ until analysis within 8 days by the end of the sampling campaign. Urine samples were collected at both pre-shift and post-shift and stored at $-80{ }^{\circ} \mathrm{C}$ until analysis. All participants gave their informed consent and the study was approved by the Ethics Committee of the Lebanese University.

\subsection{Analysis of BTEX}


125 (2011). Exposure to airborne BTEX was assessed by using GABIE (Gas Adsorbent Badge for

126 Individual Exposure) diffusive samplers (ARELCO, ARC20001UP, France) containing

127 activated charcoal cartridge. After sampling, the badges were sealed, preserved at $-80{ }^{\circ} \mathrm{C}$ and

128 sent for analysis to the "Centre Commun de Mesure", ULCO, Dunkerque (France). Briefly,

129 BTEX were desorbed from the activated charcoal by using $2 \mathrm{~mL}$ of benzene-free carbon

130 disulfide (Sigma, France) under agitation for $15 \mathrm{~min}$. The mixture was filtered and $1 \mu \mathrm{L}$ of

131 the filtrate was analysed on a Gas Chromatograph (GC) (CP-3800, Varian USA) coupled to a

132 Mass Spectrometer (1200 TQ, Varian USA) using Factor four VF-5 ms column (0.25 mm

133 internal diameter, $30 \mathrm{~m}$, film thickness $0.25 \mu \mathrm{m}$ ). The carrier gas was helium, and the flow

134 rate was set at $1 \mathrm{~mL} / \mathrm{min}$. The $\mathrm{GC}$ oven was held at $40{ }^{\circ} \mathrm{C}$ for $5 \mathrm{~min}$ and then increased to 310

$135{ }^{\circ} \mathrm{C}$ at the rate of $5{ }^{\circ} \mathrm{C} / \mathrm{min}$. The recovery rate of extraction of benzene was $99 \%$. Data were 136 averaged over each sampling period.

137

2.4. Determination of urinary metabolites

2.4.1. Urinary $t, t$-muconic acid (t,t-MA)

140 Urine samples were thawed at room temperature for $15 \mathrm{~min}$ with frequent stirring, and

141 then centrifuged at $3000 \mathrm{~g}$ for $10 \mathrm{~min}$. Aliquots of alkalinized urine were applied to a strong

142 anion exchange (SAX $500 \mathrm{mg} 3 \mathrm{cc}$ ) column (Varian) and subsequently washed with $3 \mathrm{~mL} 1 \%$

143 (v/v) acetic acid. The $t, t$-muconic acid was eluted with $3 \mathrm{~mL} 10 \%(\mathrm{v} / \mathrm{v})$ aqueous acetic acid

144 and then analyzed by HPLC equipped with a UV detector (Waters, Milford, USA). The 145 concentration of $t, t$-MA was expressed as $\mu \mathrm{g} / \mathrm{g}$ creatinine. The limit of detection (LOD) was 3

$146 \mu \mathrm{g} \mathrm{L}^{-1}$. The limit of quantification (LOQ) was $10 \mu \mathrm{g} \mathrm{L}^{-1}$. The coefficient of variation of the 147 method was within $12 \%$ for inter-day determination. 

Four hundred microlitres of urine containing $10 \mu \mathrm{L}$ of deuterated internal standards at

$15110 \mu \mathrm{g} \mathrm{mL}^{-1}$ were added to $0.400 \mathrm{~mL}$ of sodium acetate buffer at $10 \mathrm{mM}$ and $1 \mathrm{~mL}$ of distilled

152 water. Sample mixture was homogenized for $0.5 \mathrm{~min}$ and centrifuged at $5000 \mathrm{rpm}$ for $5 \mathrm{~min}$.

153 The supernatant was loaded onto Oasis ${ }^{\circledR}$ MAX $3 \mathrm{cc} / 60 \mathrm{mg}$ cartridge (Waters, Milford, USA)

154 pre-conditioned with $2 \mathrm{~mL}$ of methanol (Chromanorm HPLC grade) followed by $2 \mathrm{~mL}$ of

155 deionized water (Versol ${ }^{\circledR}$, Aguettant, Lyon, France). The extraction cartridge was washed

156 successively with $2 \mathrm{~mL}$ of distilled water and $2 \mathrm{~mL}$ of methanol. Following the final wash, 157 the cartridges were dried for $1 \mathrm{~min}$. Analytes elution was effected using $2 \mathrm{~mL}$ of a $1 \%$ formic

158 acid in methanol (v/v). The extracted fraction was evaporated under a stream of nitrogen gas, 159 then dissolved in $0.1 \mathrm{~mL} \mathrm{0.1 \%} \mathrm{formic} \mathrm{acid/acetonitril} \mathrm{(95:5} \mathrm{v/v)} \mathrm{(Sigma-Aldrich,} \mathrm{France).}$

160 Urinary S-PMA was analyzed using a Waters Acquity ultra-performance liquid 161 chromatography (UPLC) performed on a Acquity UPLC BEH C18 (1.7 $\mu \mathrm{m}, 2.1 \mathrm{x} 100 \mathrm{~mm})$ at

$16250{ }^{\circ} \mathrm{C}$. Samples $(15 \mu \mathrm{L})$ were injected onto the column using a gradient elution of acetonitril

163 and $0.01 \%$ aqueous acetic acid at a flow rate of $0.4 \mathrm{~mL} / \mathrm{min}$. Mass spectrometric selective

164 detection was provided by a Waters Acquity Xevo TQD tandem mass spectrometer running

165 in negative mode. Negative ions were acquired using electrospray ionization operated in the 166 MRM (Multiple Reaction Monitoring) mode. The concentration of S-PMA was expressed as $167 \mu \mathrm{g} \mathrm{g}^{-1}$ creatinine. The LOQ was $1 \mu \mathrm{g} \mathrm{\textrm {L } ^ { - 1 }}$. mercapturic acid (DHBMA)

The preparation of urine samples for analysis of MHBMA and DHBMA was carried

172 out as previously described for the determination of urinary S-PMA. After the clean-up procedure, samples $(15 \mu \mathrm{L})$ were injected onto the column using a gradient elution of 
acetonitril and $0.1 \%$ aqueous formic acid at a flow rate of $0.4 \mathrm{~mL} / \mathrm{min}$ and were subjected to analysis by a Waters Acquity TQD tandem mass spectrometer operating in ESI-MRM mode.

176 Concentrations of urinary MHBMA and DHBMA were expressed as $\mu \mathrm{g} \mathrm{g}^{-1}$ creatinine and the 177 LOQ was $5 \mu \mathrm{g} \mathrm{L}^{-1}$ and $50 \mu \mathrm{g} \mathrm{L}^{-1}$, respectively.

178

\subsubsection{Urinary creatinine} The concentration of creatinine in the urine samples was performed by the Jaffé

181 method using a Roche Diagnostics kit (Roche Diagnostics, France). The LOD was $34 \mu \mathrm{g} \mathrm{L}^{-1}$.

\subsubsection{Cotinine assay}

Urinary cotinine levels, as the major nicotine metabolite, were analyzed using DRI cotinine enzyme immunoassay (Microgenics GmbH, Passau, Germany) to check the tobacco smoke exposure reported in the lifestyle questionnaires. Subjects with cotinine levels greater

187 than $500 \mu \mathrm{g} \mathrm{g}^{-1}$ of creatinine were considered active smokers. The LOD was $34 \mu \mathrm{g} \mathrm{L}{ }^{-1}$. All

188 the tests were performed according to the manufacturer's instructions.

\section{9}

\subsection{Statistical Analysis}

The Chi2 test was used for comparing categorical variables between groups; when

192 expected values within cells are $<5$, Fisher exact test was used. For quantitative variables

193 with normal distribution, Student test or ANOVA were used to compare between two groups.

194 In case of non normal distribution, the Mann-Whitney or Kruskal-Wallis test were used to 195 compare between mean ranks for two or different groups. Correlation analysis was performed

196 with Spearman rank order correlation. Multivariate analysis was also performed to estimate

197 the influence of BTEX levels on biomarkers. We adjusted our model on several possible

198 potential confounders including, age, BMI, estimated vehicle counts for the exposure period, 

smoking and alcohol consumption. A level of $p<0.05$ was considered statistically significant 200 (SPSS version 16.0 software).

201 
203

204

205

206

207

208

209

210

211

212

213

214

215

216

217

218

219

220

221 222 p-xylene levels.

223

224

225

226

\subsection{Demographic characteristics}

Table 1 represents the distribution of subjects with respect to age, smoking, duration of exposure and body mass index (BMI). Statistical results for alcohol current use are not shown due to poor positive responses to the related question. The two groups studied had similar demographic characteristics. On an average, the work shift was $7 \mathrm{~h} / \mathrm{d}$ and $5 \mathrm{~h} / \mathrm{d}$ for traffic and office policemen, respectively. All participants were of the same social class. Within both groups, the length of employment was $4.47 \pm 2.91$ years (mean $\pm \mathrm{SD}$ ). Urinary cotinine levels were $890 \pm 999$ and $786 \pm 770 \mu \mathrm{g} \mathrm{g}^{-1}$ creatinine for smokers and $36 \pm 15.5$ and $27 \pm 6 \mu \mathrm{g} \mathrm{g}^{-1}$ creatinine for nonsmokers sampled from traffic and office policemen, respectively. In line with WHO (WHO, 1996) recommendations, only urine samples with creatinine concentration in the range $0.3-3.0 \mathrm{~g} \mathrm{~L}^{-1}$ were considered.

\subsection{BTEX in breathing zone air}

The results of personal exposure monitoring are presented in Table 2. The levels of BTEX compounds exposure were much higher in traffic policemen than in the office population. Traffic policemen were exposed to significantly higher (14-fold) BTEX compounds concentrations than office policemen $(p<0.001)$. Traffic policemen were currently exposed to a wide range of benzene, toluene, ethylbenzene, m-xylene, o-xylene and

A close examination at the results reveals that individual exposure to benzene values are high to previously campaigns conducted in Bolognia/Italy (Maffei et al., 2005), in Ioannina/Greece (Pilidis et al., 2008), in Prague/Czech Republic (Rossnerova et al., 2009) and in Bangkok/Thailand (Arayasiri et al., 2010). It is necessary to clarify that policemen 
working outdoor were performing exclusively traffic regulation throughout the entire

228

229

230

231 level of individual exposure to benzene, to o-xylene and to $\mathrm{p}$-xylene of $3.23 \mu \mathrm{g} \mathrm{m}^{-3}$ ( $p=$ $2320.017), 2.6 \mu \mathrm{g} \mathrm{m}^{-3}(p=0.05)$ and $3.16 \mu \mathrm{g} \mathrm{m}^{-3}(p=0.05)$, respectively. No significant 233 t,t-MA levels (Table 3).

relationships were observed between individual toluene or ethylbenzene exposure levels and estimated vehicle counts for the exposure period.

Moreover, excellent spearman correlation $(p<0.001)$ were found between toluene, $\mathrm{m}$ xylene, ethylbenzene, o-xylene, p-xylene and total BTEX exposure levels in the breathing zone (Table 3): in fact, emissions and combustion products from gasoline vehicles include a large variety of chemicals and additives, e.g. toluene; when those compounds are emitted from the same source, they have a nearly constant emission ratio (Barbieri et al., 2008).

\subsection{Biomarkers of exposure}

\subsubsection{Benzene}

The median level of post-shift $t, t$-MA in traffic policemen was 13-fold higher than that of office policemen $(p<0.001) p=p=$ (Table 4$)$. The concentrations of pre- and postshift $t, t$-MA were significantly different in office policemen $(p=0.03)$. The concentration of post-shift S-PMA in traffic policemen was not shown to be significantly different from that of the office policemen. No significant associations were found between personal benzene, toluene, ethylbenzene, m-xylene, o-xylene, p-xylene or total BTEX exposure and S-PMA or 

that of office policemen $(p<0.001)$. The concentration of post-shift MHBMA in traffic

254 policemen was not shown to be significantly different from that of the office policemen 255 (Table 4). The median level of pre-shift DHBMA in traffic policemen was 2.7-fold higher 256 than that of office policemen $(p<0.001)$ and 2.8 -fold higher at post-shift $(p<0.01)$ 257 compared between traffic and office policemen. A strong significant correlation between 258 personal toluene, ethylbenzene, m-xylene, o-xylene, p-xylene or total BTEX exposure and urinary post-shift DHBMA (Table 3). The association between personal total BTEX exposure and post-shift DHBMA may indicate the same source of emissions, i.e. automobile 261 exhaust.Significant difference was found between sub-groups of non-smokers, light to moderate smokers and heavy smokers only at pre-shift $t, t$-MA levels $(p=0.01)$ (KruskalWallis test). Median levels of urinary post-shift MHBMA in the urine of heavy smokers was 5.6-fold higher than in non-smokers $(p=0.025)$ (Mann-Whitney test). Urinary S-PMA and DHBMA values did not discriminate exposure resulting from smoking habits and no

266 significant difference was found between smokers and non-smokers (data not shown).

267 Nevertheless, significant difference was found between sub-groups of non-smokers, light to moderate smokers and heavy smokers at pre-shift and post-shift MHBMA results $(p=0.007$ and $p=0.003$ ) (Kruskal-Wallis test). Median levels of urinary post-shift MHBMA in the urine of light to moderate smokers and heavy smokers were, respectively, 4.9-fold and 4.1fold higher than in non-smokers.

\subsection{Multiple regression analysis}


277 0.001), showing that there is a difference in sensitivity between the two urinary metabolites

278 of BD exposure measured in this study. Nevertheless, age was negatively related to $279 \operatorname{logDHBMA}(\beta=-0.286 ; p=0.045)$. 


\section{DISCUSSION}

282

283

284

285

286

287

288

289

290

291

292

293

294 These levels were far below the Occupational Safety and Health Administration (OSHA)

295

296

297

298

299

300

301 302 in Beirut area that are highly traffic congested and to the fact that in Lebanon personal

303 vehicles are the prevailing mode of transport.

304 In addition, individual exposure to benzene (mean $=48.8 \mu \mathrm{g} \mathrm{m}^{-3}$ ) in the traffic policemen in 305 this study was higher than that measured in traffic policemen in Bologna/Italy (mean = 17.3

Environmental exposure to VOCs among workers has been already described elsewhere (Barbieri et al., 2008; Pilidis et al., 2008; Arayasiri et al., 2010; Manini et al., 2010), whereas it has not been reported yet for Beirut traffic policemen. For these reasons, we have undertaken an extensive investigation of the occupational exposure to VOCs, notably, benzene and $\mathrm{BD}$, which are carcinogenic substances in urban air from incomplete combustion of fossil fuels, through personal air monitoring, as well as through the use of biomarkers of exposure. In a previous studies conducted in Beirut, it has been reported that the spatial distribution of VOCs emissions are mostly over Beirut and its suburbs, where there are dense populations and heavy traffic (Waked et al., 2012). While ambient air monitoring of VOCscompounds has not been reported at roadsides in Beirut area, individual exposure levels to exposure limits, 8-h time weight average of $3.2 \mathrm{mg} \mathrm{m}^{-3}$ for benzene (OSHA, 1999), of 375 $\mathrm{mg} \mathrm{m}^{-3}$ for toluene (OSHA, 1999), of $435 \mathrm{mg} \mathrm{m}^{-3}$ for ethylbenzene (OSHA, 1999) and of 435 $\mathrm{mg} \mathrm{m}^{-3}$ for xylene (OSHA, 2008). Moreover, our results have shown that each exposure to one vehicle increases the level of individual exposure to benzene, $\mathrm{o}-\mathrm{xylene}$ and to $\mathrm{p}$-xylene due to the fact that xylene is primarily released from motor vehicle exhaust where it is used as a solvent (Kandyala et al., 2010). Evidence presented herein extended these observations by showing that these personal exposure levels indicated higher emissions related to vehicles 
$306 \mu \mathrm{g} \mathrm{m}^{-3}$ ) (Barbieri et al., 2008), in Ioannina/Greece (mean $=30 \mu \mathrm{g} \mathrm{m}^{-3}$ ) (Pilidis et al., 2008), in

307 Prague/Czech Republic (mean concentration in February $=6.99$ and in May $=4.53 \mu \mathrm{g} \mathrm{m}^{-3}$ )

308 (Rossnerova et al., 2009) and in Bangkok/Thailand (mean=38.24 $\mu \mathrm{g} \mathrm{m}^{-3}$ ) (Arayasiri et al.,

309 2010). The same for other BTEX compounds, individual exposure to toluene, ethylbenzene,

$310 \mathrm{~m}$-xylene and o-xylene in the traffic policemen in this study were strongly higher than that

311 measured in traffic policemen in Prague/Czech Republic (mean concentration in May =

$31213.99,3.25,10.95$ and $3.75 \mu \mathrm{g} \mathrm{m}^{-3}$, respectively) (Rossnerova et al., 2009). Difference in

313 many of environment factors, such as traffic characteristics, quality of fuel, meteorological

314 conditions, building characteristics of the area, and difference in physical activity in the

315 workplace may contribute to the difference in the levels of individual VOCs exposure.

316 Although excellent spearman correlations $(p<0.001)$ were found between toluene,

317 ethylbenzene, m-xylene, o-xylene, $\mathrm{p}$-xylene and total BTEX exposure levels, we did not find

318 significant correlation between benzene and none of BTEX compounds. Even if these

319 compounds were emitted from the same source (Barbieri et al., 2008), we suggest that lack of

320 any such correlation may be due to the fact that some individual values reported for benzene

321 exposure were below the $\operatorname{LOD}\left(<0.3 \mu \mathrm{g} \mathrm{m}^{-3}\right)$.

322 In our study, $t, t$-MA concentration was found to be a better indicator of the levels of

323 benzene exposure than S-PMA. Urinary post-shift $t, t$-MA levels were significantly higher in

324 traffic policemen compared with office policemen (Table 4). In a previous studies with Italian

325 policemen who had levels of individual benzene exposure of $17.3 \mu \mathrm{g} \mathrm{m}^{-3}$ (Barbieri et al.,

326 2008), i.e. lower than in this study, post-shift $t, t$-MA levels were comparable $\left(44 \mu \mathrm{g} \mathrm{m}^{-3}\right.$ for

327 non-smokers and $120 \mu \mathrm{g} \mathrm{m}^{-3}$ for smokers) (Manini et al., 2010), while the post-shift S-PMA

328 levels were much lower in both studies (approximately 7-fold). However, the levels of S-

329 PMA and $t, t$-MA were not significantly different between pre- and post-shift samples,

330 excepted for $t, t$-MA results within office policemen group $(p=0.03)$. A close examination at 
331 individual results reveals a decrease of urinary S-PMA by the end of the work shift. A

332 previous study, conducted by Qu and colleagues (2000), estimated the urinary half life of

333 elimination $\left(t^{1} / 2\right)$ of S-PMA to be $12.8 \mathrm{~h}$. Thus, higher levels in pre-shift S-PMA could be the

334 result of cumulative exposure to benzene during the previous day. Moreover, ingestion of

335 unknown amounts of dietary sorbic acid and glutathione-S-transferase (GSTM1, GSTT1 and

336 GSTA1) polymorphism may influence variability in metabolites levels (Manini at el., 2010).

337 Moreover, we denote some urinary S-PMA and $t, t$-MA values below the LOQ $\left(<1 \mu \mathrm{g} \mathrm{L}^{-1}\right.$

338 and $<10 \mu \mathrm{g} \mathrm{L}^{-1}$, respectively). It seems that biotransformation of benzene to its metabolites is

339 reduced by co-exposure to other chemicals and additives emitted from gasoline vehicles

340 (Barbieri et al., 2008) such as toluene (a competitive inhibitor of benzene for CYP

341 metabolism) which would affect the pharmacokinetics and metabolism of benzene, including

342 conjugation with glutathione and subsequent mercapturic acid excretion (Johnson et al.,

343 2007). Accordingly to previous studies, no significant associations were found between

344 personal benzene or personal BTEX compounds exposure and S-PMA or $t, t$-MA levels

345 (Table 3) (Barbieri et al., 2008; Arayasiri et al., 2010). The lack of any such correlation may

346 be due to the confounding effect of smoking on metabolite excretion (Carrieri et al., 2010;

347 2012) or to the fact that some values reported for benzene exposure, urinary PMA and $t, t$-MA

348 were below the LOQ. Moreover, urinary $t, t$-MA level may be affected by the diet of the

349 subjects examined (Carrieri et al., 2010; Weisel, 2010). For BD exposure in ambient air, a

350 limited number of biomonitoring studies have been conducted. Pre- and post-shift DHBMA

351 levels in traffic policemen were significantly higher than in office policemen (Table 4). We

352 found that urinary pre-shift MHBMA and DHBMA concentrations in traffic policemen were

353 significantly higher than office policemen, which indicates that elimination of those

354 metabolites from previous BD exposure is not yet completed. This suggests that the average

355 urinary $\mathrm{t}^{1 / 2}$ of MHBMA and DHBMA is somewhat protracted compared to the $t^{1 / 2}$ of other 
mercapturic acids, such as the benzene metabolite S-PMA and $t, t$-MA, which have an average t¹/2 of $12.8 \mathrm{~h}$ and $13.7 \mathrm{~h}$, respectively (Qu et al., 2000; van Sittert et al., 2000; Albertini et al., 2003). A close examination at individual results reveals a decrease of urinary MHBMA level by the end of the work shift. In view of the complexity of the metabolic pathways involved in

360 the biotransformation of butadiene, we expected an effect of the genetic polymorphisms in

361 xenobiotic metabolizing enzymes which affects the excretion of urinary metabolites. We also suggest that co-exposure to aromatic hydrocarbons (e.g. toluene) may cause a decrease in epoxide metabolites levels, namely formation via cytochrome P-450 2E1, and a decreased

364 excretion urinary metabolites of BD (Johnson et al., 2007; Vacek et al., 2010; Fustinoni et al., 365 2012).

366 Alternatively, DHBMA concentrations were found to be a better indicator of the levels of 367 BD exposure in urban air than MHBMA, as reported previously (Sapkota et al., 2006). Preand post-shift DHMBA levels could significantly distinguish between office and traffic policemen and showed a better correlation with personal total BTEX exposure.

Multiple regression analysis applied to evaluate the contribution of each predictor to the variability of urinary biomarkers of benzene and BD. Traffic and office policemen stated to have smoked during working. Although levels of BD in the breathing zone of study subjects have not been reported, it seems that smoking habits influence the total intake of BD (WHO, 2000). Unexpectedly, there was not a marked effect of smoking habits on DHBMA. Multiple

375 regression analysis showed that the levels of individual BTEX exposure significantly 376 contributed to increase urinary DHBMA $(\beta=0.535, \mathrm{p}<0.001)$. Accordingly, DHBMA values 377 did not discriminate exposure resulting from smoking habits and no significant difference was found between smokers and non-smokers. and $\mathrm{BD}$ at the roadside in central Beirut, are potentially at a higher risk for development of 
381 diseases such as cancer than office policemen. Further studies need to focus on the lifestyle 382 and genetic factors that may affect the background levels of S-PMA, $t, t$-MA, MHBMA and

383 DHBMA. Given chaotic traffic conditions, quality of fuel, high rate of passenger cars

384 ownership, meteorological conditions, building characteristics of the area, and high pollution

385 rates observed in Beirut, increased urinary exposure biomarker would result in a higher risk

386 in the exposed subjects. Accordingly, public authorities should particularly set policies aimed 387 to reduce traffic-related air pollution. 
$389 \quad$ Funding

390

This research was funded by Agence Universitaire de la Francophonie (PCSI;

391 reference: 6317PS011)

392

393 Acknowledgments

394 The authors express their sincere thanks to the Maj. Gen. Ashraf Rifi, General

395 Director of the Lebanese Internal Security Forces for his encouragement, and to the Major

396 Elie Kallas and the Major Hanna Laham for providing facilities during the study. The authors

397 declare that there is no conflict of interest.

398 


\section{References}

400 Abbas, I., Garçon, G., Saint-Georges, F., Andre, V., Gosset, P., Billet, S., Goff, J.L., Verdin,

401

402

403

404

405

406

407

408

409

410

411

412

413

414

415

416

417

418

419

420

421

422

423

A., Mulliez, P., Sichel, F., Shirali, P, 2013. Polycyclic aromatic hydrocarbons within airborne particulate matter $\left(\mathrm{PM}_{2.5}\right)$ produced DNA bulky stable adducts in a human lung cell coculture model. J Appl Toxicol. 33:109-19.

Albertini, R.J., Sram, R.J., Vacek, P.M., Lynch, J., Wright, M., Nicklas, J.A., Boogaard, P.J., Henderson, R.F., Swenberg, J.A., Tates, A.D., Ward, J.B., Jr., 2001. Biomarkers for assessing occupational exposures to 1,3-butadiene. Chem Biol Interact. 135:429-453.

Arayasiri, M., Mahidol, C., Navasumrit, P., Autrup, H., Ruchirawat, M., 2010. Biomonitoring of benzene and 1,3-butadiene exposure and early biological effects in traffic policemen. Sci Total Environ. 408:4855-62.

Avogbe, P., Ayi-Fanou, L., Cachon, B., Chabi, N., Delbende, A., Dewaele, D., Aissi, F., Cazier, F., and Sanni A., 2011. Hematological changes among Beninese motor-bike taxi drivers exposed to benzene by urban air pollution. Afr. J. Environ. Sc. Technol. 5: 464472

Barbieri, A., Violante, F.S., Sabatini, L., Graziosi, F., Mattioli, S., 2008. Urinary biomarkers and low-level environmental benzene concentration: assessing occupational and general exposure. Chemosphere. 74:64-9.

Billet, S., Paget, V., Garçon, G., Heutte, N., André, V., Shirali, P., Sichel, F., 2010. Benzeneinduced mutational pattern in the tumour suppressor gene TP53 analysed by use of a functional assay, the functional analysis of separated alleles in yeast, in human lung cells. Arch Toxicol. 84:99-107.

Carugno, M., Pesatori, A.C., Dioni, L., Hoxha, M., Bollati, V., Albetti, B., Byun, H.M., Bonzini, M., Fustinoni, S., Cocco, P., Satta, G., Zucca, M., Merlo, D.F., Cipolla, M., Bertazzi, P.A., Baccarelli, A., 2012. Increased mitochondrial DNA copy number in 
occupations associated with low-dose benzene exposure. Environ Health Perspect. 120:210-5.

426 Cheng, X., Zhang, T., Zhao, J., Zhou, J., Shao, H., Zhou, Z., Kong, F., Feng, N., Sun, Y., 427 Shan, B., Xia, Z., 2012. The association between genetic damage in peripheral blood 428 lymphocytes and polymorphisms of three glutathione S-transferases in Chinese workers exposed to 1,3-butadiene. Mutat Res. 750:139-46.

430 Clifford P. Weisel, 2010. Benzene exposure: An overview of monitoring methods and their 431 findings. Chem-Biol Interact. 184:58-66

432 Dagher, Z., Garçon, G., Billet, S., Gosset, P., Ledoux, F., Courcot, D., Aboukais, A., Shirali, 433 P., 2006. Activation of different pathways of apoptosis by air pollution particulate matter 434 (PM2.5) in human epithelial lung cells (L132) in culture. Toxicol. 225:12-24.

435 EU-RAR, 2002. European Union Risk Assessment Report 1,3-Butadiene.

436 Fustinoni, S., Campo, L., Satta, G., Campagna, M., Ibba, A., Tocco, M., Atzeri, S., Avataneo, 437 G., Flore, C., Meloni, M., Bertazzi, P., Cocco, P., 2012. Environmental and lifestyle 438 factors affect benzene uptake biomonitoring of residents near a petrochemical plant. $439 \quad$ Environ Int. 39: 2-7.

440 Fustinoni, S., Consonni, D., Campo, L., Buratti, M., Colombi, A., Pesatori, A.C., Bonzini, 441 M., Bertazzi, P.A., Foà, V., Garte, S., Farmer, P.B., Levy, L.S., Pala, M., Valerio, F., 442 Fontana, V., Desideri, A., Merlo, D., 2005. Monitoring low benzene exposure: 443 comparative evaluation of urinary biomarkers, influence of cigarette smoking, and genetic 444 polymorphisms. Cancer Epidemiol. Biomarkers Prev. 14, 2237-2244.

445 Han, X., Naeher, L., 2006. A review of traffic-related air pollution exposure assessment studies in the developing world. Environ Int. 32:106-20 
IARC, 2008. Monographs On The Evaluation Of The Carcinogenic Risk Of Chemicals To Humans. Volume 97. 1,3-Butadiene, Ethylene Oxide and Vinyl Halides (http://monographs.iarc.fr).

IARC, 2009. A Review Of Human Carcinogens, Part F: Chemical Agents And Related Occupations. Lancet Oncol 10:1143-1144.

452

Ibrahim, K.S., Amer, N.M., El-Dossuky, E.A., Emara, A.M., El-Fattah, A.E., Shahy, E.M., 2012. Hematological effects of benzene exposure with emphasis on muconic acid as biomarker in exposed workers. Toxicol Ind Health. 0748233712458141.

Johnson, E.S., Langård, S., Lin, Y.S., 2007. A critique of benzene exposure in the general population. Sci Total Environ. 374:183-98

Kamal, A., Malik, R.N., Fatima, N., Rashid, A., 2012. Chemical exposure in occupational settings and related health risks: a neglected area of research in Pakistan. Environ Toxicol Pharmacol. 34:46-58.

460

Kandyala, R., Raghavendra, S.P., Rajasekharan, S.T., 2010. Xylene: An overview of its health hazards and preventive measures. J Oral Maxillofac Pathol. 14:1-5.

462 Knibbs, L.D., Morawska, L., 2012. Traffic-related fine and ultrafine particle exposures of professional drivers and illness: An opportunity to better link exposure science and epidemiology to address an occupational hazard? Environ Int. 49:110-4.

465 Koturbash, I., Scherhag, A., Sorrentino, J., Sexton, K., Bodnar, W., Tryndyak, V., 466 Latendresse, J.R., Swenberg, J.A., Beland, F.A., Pogribny, I.P., Rusyn, I., 2011. Epigenetic alterations in liver of C57BL/6J mice after short-term inhalational exposure environmental benzene: Micronucleus frequencies and haematological values in traffic police working in an urban area. Mutat. Res. $583: 1-11$. 
472

473

474

475

476

477

478

479

480

481

482

483

484

485

486

487

488

489

490

491

492

493

494

495

496

Manini, P., De Palma, G., Andreoli, R., Mozzoni, P., Poli, D., Goldoni, M., Petyx, M., Apostoli, P., Mutti, A., 2010. Occupational exposure to low levels of benzene: Biomarkers of exposure and nucleic acid oxidation and their modulation by polymorphic xenobiotic metabolizing enzymes. Toxicol Lett. 193:229-35.

Occupational Safety and Health Administration (OSHA), US. Department of Labor. OSHA standard -29 CFR 1910.1028 (7/1/1999), from National Library of Medicine, HSDB: Benzene, CASRN: 71-43-2; $1999 \quad$ (http://toxnet.nlm.nih.gov/cgibin/sis/search/f?./temp/ F3eDcl:1 Last accessed 07/12/2012).

OSHA, OSHA standard -29 CFR 1910.1000 (2/10/2008), from U.S. National Archives and Records Administration's Electronic Code of Federal Regulations, HSDB: Xylene, CASRN: 1330-20-7; 2008 (Last accessed 07/12/2012).

OSHA, OSHA standard -29 CFR 1910.1000 (7/1/1999), from National Library of Medicine, HSDB: Toluene, CASRN: 108-88-3; 1999 (Last accessed 07/12/2012).

OSHA, OSHA standard -29 CFR 1910.1000 (7/1/1999), from National Library of Medicine, HSDB: Ethylbenzene, CASRN: 100-41-4; 1999 (Last accessed 07/12/2012).

Pamela M. Vacek, Richard J. Albertini, Radim J. Sram, Patricia Upton, James A. Swenberg, Hemoglobin adducts in 1,3-butadiene exposed Czech workers: Female-male comparisons, Chemico-Biological Interactions, Volume 188, Issue 3, 5 December 2010, Pages 668-676.

Peluso, M., Bollati, V., Munnia, A., Srivatanakul, P., Jedpiyawongse, A., Sangrajrang, S., Piro, S., Ceppi, M., Bertazzi, P.A., Boffetta, P., Baccarelli, A.A., 2012. DNA methylation differences in exposed workers and nearby residents of the Ma Ta Phut industrial estate, Rayong, Thailand. Int J Epidemiol. 41:1753-60.

Pilidis, G.A., Karakitsios, S.P., Kassomenos, P.A., Kazos, E.A., Stalikas, C.D., 2009. Measurements of benzene and formaldehyde in a medium sized urban environment. 
Indoor/outdoor health risk implications on special population groups. Environ Monit Assess. 150:285-94.

499

Qu, Q., Melikian, A.A., Li, G., Shore, R., Chen, L., Cohen, B., Yin, S., Kagan, M.R., Li, H.,

500

501 Meng, M., Jin, X., Winnik, W., Li, Y., Mu, R., Li, K., 2000. Validation of biomarkers in

\section{2} humans exposed to benzene: urine metabolites. Am J Ind Med. 37:522-31.

503

Rekhadevi, P.V., Rahman, M.F., Mahboob, M., Grover, P., 2010. Genotoxicity in filling 503 station attendants exposed to petroleum hydrocarbons. Ann Occup Hyg. 54:944-54.

504

505

506

Rossnerova, A., Spatova, M., Rossner, P., Solansky, I., Sram, R.J., 2009. The impact of air pollution on the levels of micronuclei measured by automated image analysis. Mutat Res. 669:42-7.

507

Ruchirawat, M., Navasumrit, P., Settachan, D., 2010. Exposure to benzene in various susceptible populations: co-exposures to 1,3-butadiene and PAHs and implications for carcinogenic risk. Chem Biol Interact. 184:67-76.

Sangaraju, D., Goggin, M., Walker, V., Swenberg, J., Tretyakova, N., 2012. NanoHPLCnanoESI(+)-MS/MS quantitation of bis-N7-guanine DNA-DNA cross-links in tissues of B6C3F1 mice exposed to subppm levels of 1,3-butadiene. Anal Chem. 84:1732-9.

Sapkota, A., Halden, R.U., Dominici, F., Groopman, J.D., Buckley, T.J., 2006. Urinary biomarkers of 1,3-butadiene in environmental settings using liquid chromatography

516 Seow, W.J., Pesatori, A.C., Dimont, E., Farmer, P.B., Albetti, B., 2012. Urinary Benzene Biomarkers and DNA Methylation in Bulgarian Petrochemical Workers: Study Findings and Comparison of Linear and Beta Regression Models. PLoS One 7:e50471. butadiene as a basis for cancer risk assessment. Toxicol Sci. 56:189-202.Tabish, A.M., 
522 Poels, K., Hoet, P., Godderis, L., 2012. Epigenetic factors in cancer risk: effect of 523 chemical carcinogens on global DNA methylation pattern in human TK6 cells. PLoS $524 \quad$ One. 7:e34674.

525 Waked, A., Afif, C., Seigneur, C., 2012. An atmospheric emission inventory of 526 anthropogenic and biogenic sources for Lebanon. Atmos. Environ. 50,88-96

527 WHO, 1996. Biological Monitoring Of Chemical Exposure In The Workplace, vol. 1, 528 Geneva: World Health Organization.

529 WHO, 2000. Butadiene Air Quality Guidelines. Chapter 5.3 - Second Edition. Regional $530 \quad$ Office for Europe, Copenhagen, Denmark.

531 Xiang, M., Ao, L., Yang, H., Liu, W., Sun, L., Han, X., Li, D., Cui, Z., Zhou, N., Liu, J., Cao, 532 J., 2012. Chromosomal damage and polymorphisms of metabolic genes among 1, 3533 butadiene-exposed workers in a matched study in China. Mutagenesis. 27:415-21. 
535 TABLES

536 
537 Table 1. Summary of information collected by questionnaire.

\begin{tabular}{lccc}
\hline & Traffic & Office & $p$ value \\
& policemen & policemen & \\
& $(\mathrm{n}=24)$ & $(\mathrm{n}=23)$ & \\
\hline Age (years, mean \pm SD) & $27.4 \pm 4.6$ & $29.1 \pm 3.6$ & 0.06 \\
Percentage of never/current-smokers & 37 & 56 & 0.19 \\
Cigarettes/d (mean \pm SD) & $21 \pm 18$ & $26.2 \pm 23$ & 0.633 \\
Sampling period $(\mathrm{h}$, mean \pm SD) & $33.25 \pm 3.1$ & $45.2 \pm 3.4$ & $<0.001$ \\
BMI $\left(\mathrm{kg} \mathrm{m}{ }^{-2}\right.$, mean \pm SD) & $25.6 \pm 4.6$ & $27.9 \pm 4.3$ & 0.125 \\
\end{tabular}

538 Significant at $p<0.05$. Student's t test. 
539 Table 2. Distribution of individual VOCs exposure in subgroups of policemen. Values are expressed as geometric medians, means and 540 geometric standard deviations. Concentrations are expressed as $\mu \mathrm{g} / \mathrm{m}^{3}$.

\begin{tabular}{|c|c|c|c|c|c|c|c|c|}
\hline \multicolumn{5}{|c|}{ Traffic policemen } & \multicolumn{4}{|c|}{ Office policemen } \\
\hline Parameter & \multicolumn{3}{|c|}{$(n=24)$} & Parameter & \multicolumn{4}{|c|}{$(n=23)$} \\
\hline Benzene $(n=21)$ & 0.3 & $0.3-867.8$ & $48.8 \pm 189.3$ & Benzene $(n=22)$ & 0.3 & $0.3-10.8$ & $1.2 \pm 2.3$ & n.s. \\
\hline Ethylbenzene $(n=21)$ & 58.1 & $6.7-5845.2$ & $662.3 \pm 1420.3$ & Ethylbenzene $(\mathrm{n}=22)$ & 4.5 & $0.88-19.1$ & $5.7 \pm 4.4$ & $<0.001$ \\
\hline mXylene $(\mathrm{n}=21)$ & 102.8 & 29.1-1209.6 & $196.7 \pm 287.6$ & mXylene $(n=22)$ & 2.0 & $0.65-10.6$ & $2.5 \pm 2.2$ & $<0.001$ \\
\hline oXylene $(\mathrm{n}=21)$ & 21.3 & $1.0-1839.1$ & $177.7 \pm 432.3$ & oXylene $(\mathrm{n}=22)$ & 1.7 & $0.58-5.64$ & $2.0 \pm 1.3$ & $<0.001$ \\
\hline
\end{tabular}

541 Significant at $p<0.05$. Mann-Whitney test, n.s. = not significant. 
543 Table 3. Spearman correlation coefficients between different variables.

\begin{tabular}{|c|c|c|c|c|c|c|c|c|c|c|c|c|c|c|}
\hline & Tol & Ethylbz & mXyl & oXyl & $\mathrm{pXyl}$ & BTEX & S-PMA $^{1}$ & $\mathrm{~S} \mathrm{PMA}^{2}$ & $t, t-\mathrm{MA}^{1}$ & $t, t-\mathrm{MA}^{2}$ & MHBMA $^{1}$ & MHBMA $^{2}$ & DHBMA $^{1}$ & DHBMA $^{2}$ \\
\hline $\mathrm{Bz}$ & - & - & - & - & - & - & - & - & - & - & - & - & - & - \\
\hline Tol & & $0.962^{* *}$ & $0.982^{* *}$ & $0.939^{* *}$ & $0.933^{* *}$ & $0.989^{* *}$ & $0.358^{*}$ & - & - & - & - & - & $0.505^{* *}$ & $0.610^{* *}$ \\
\hline Ethylbz & & & $0.965^{* *}$ & $0.931^{* *}$ & $0.950^{* *}$ & $0.975^{* *}$ & $0.354^{*}$ & - & - & - & $0.317^{*}$ & - & $0.496^{* * *}$ & $0.639^{* *}$ \\
\hline mXyl & & & & $0.951^{* *}$ & $0.944^{* *}$ & $0.988^{* *}$ & $0.381^{*}$ & - & - & - & $0.357^{*}$ & - & $0.490^{* *}$ & $0.607^{* *}$ \\
\hline oXyl & & & & & $0.946^{* *}$ & $0.944^{* *}$ & $0.394^{* *}$ & - & - & - & - & - & $0.411^{* *}$ & $0.565^{* *}$ \\
\hline pXyl & & & & & & $0.943^{* *}$ & $0.398^{*}$ & - & - & - & - & - & $0.370^{*}$ & $0.597^{* *}$ \\
\hline BTEX & & & & & & & $0.401^{* *}$ & - & - & - & $0.345^{*}$ & - & $0.495^{* *}$ & $0.616^{* *}$ \\
\hline S-PMA $^{1}$ & & & & & & & & $0.467^{* *}$ & $0.464^{* * *}$ & - & $0.389^{* *}$ & - & $0.384^{* *}$ & $0.356^{*}$ \\
\hline S-PMA ${ }^{2}$ & & & & & & & & & - & - & - & $0.374^{*}$ & - & $0.320^{*}$ \\
\hline$t, t-\mathrm{MA}^{1}$ & & & & & & & & & & - & $0.385^{* *}$ & - & - & - \\
\hline$t, t-\mathrm{MA}^{2}$ & & & & & & & & & & & - & - & - & - \\
\hline MHBMA $^{1}$ & & & & & & & & & & & & $0.352^{*}$ & $0.538^{* *}$ & $0.540^{* *}$ \\
\hline MHBMA $^{2}$ & & & & & & & & & & & & & - & - \\
\hline DHBMA $^{1}$ & & & & & & & & & & & & & & $0.716^{* *}$ \\
\hline
\end{tabular}


544 Missing values correspond to lack of correlation between parameters. Only significant data are represented. ${ }^{1}$ Pre-shift; ${ }^{2}$ Post-shift. ${ }^{* *} p<0.001$; $545 * 0<0.05$ 
546 Table 4. Biomarkers of exposure in traffic and office policemen.

547

\begin{tabular}{lll}
\hline Parameter & \multicolumn{2}{l}{ Study groups } \\
\cline { 2 - 3 } & Traffic policemen & Office policemen \\
\hline Urinary $t, t-M A(\mu \mathrm{g} / \mathrm{g}$ creatinine $)$ & & \\
Pre-shift & $64.7 \pm 141.5$ & $14 \pm 13.3$ \\
& $8.2(3-586.7)$ & $11.2(2.5-56.5)$ \\
Post-shift & $(\mathrm{n}=24)$ & $(\mathrm{n}=23)$ \\
& $84.4 \pm 100.6^{\mathrm{a}}$ & $55.5 \pm 87^{*}$ \\
& $61(2.4-444.8)$ & $18.3(2.5-343.4)$ \\
& $(\mathrm{n}=24)$ & $(\mathrm{n}=22)$
\end{tabular}

Urinary S-PMA ( $\mu \mathrm{g} / \mathrm{g}$ creatinine)

$\begin{array}{lll}\text { Pre-shift } & 6.2 \pm 6^{\mathrm{a}} & 2.6 \pm 2 \\ & 4(1.1-25) & 1.7(0.9-8.1) \\ & (\mathrm{n}=24) & (\mathrm{n}=23) \\ \text { Post-shift } & 5.3 \pm 9 & 2.7 \pm 2.4 \\ & 2.6(0.5-45.5) & 1.9(0.4-10.2) \\ & (\mathrm{n}=24) & (\mathrm{n}=22)\end{array}$

Urinary MHBMA $(\mu \mathrm{g} / \mathrm{g}$ creatinine)

$\begin{array}{lll} & 24.7 \pm 23.3^{\mathrm{a}} & 17.7 \pm 38.7 \\ & 20.1(2.4-108.3) & 3.1(1.3-147.6) \\ & (\mathrm{n}=24) & (\mathrm{n}=23) \\ \text { Post-shift } & 18.7 \pm 20.1 & 18.8 \pm 31 \\ & 10.2(0.2-88.6) & 7.5(1.2-120) \\ & (\mathrm{n}=24) & (\mathrm{n}=22)\end{array}$


Urinary DHBMA $(\mu \mathrm{g} / \mathrm{g}$ creatinine $)$

$\begin{array}{lll}\text { Pre-shift } & 180.4 \pm 73.8^{\mathrm{a}} & 69.2 \pm 43.6 \\ & 182.9(47.6-333.3) & 66.5(13.2-239.3) \\ & (\mathrm{n}=24) & (\mathrm{n}=23) \\ \text { Post-shift } & 207.5 \pm 112.2^{\mathrm{b}} & 73.3 \pm 45.3 \\ & 188.6(80-588.6) & 67.4(23.9-186.7) \\ & (\mathrm{n}=23) & (\mathrm{n}=22)\end{array}$

Urinary Cotinine $(\mu \mathrm{g} / \mathrm{g}$ creatinine)

$\begin{array}{lll}\text { Pre-shift } & 767.8 \pm 1138.5^{\mathrm{a}} & 188.6 \pm 339.2 \\ & 486.9(16.1-5240) & 24.6(8.5-1200.8) \\ & (\mathrm{n}=24) & (\mathrm{n}=23) \\ \text { Post-shift } & 601.0 \pm 780.6 & 205.5 \pm 393.2 \\ & 459.3(12.1-3583.9) & 19.9(7.9-1362.4) \\ & (\mathrm{n}=24) & (\mathrm{n}=22)\end{array}$

548 Values are expressed as mean \pm SD on the first line and median (min-max) on the second line 549 of each parameter.

550 Statistically significant difference from office policemen at ${ }^{\mathrm{a}} p<0.001$ or ${ }^{\mathrm{b}} p<0.01$.

$551 *$ Statistically significant difference from the corresponding pre-shift at $p=0.03$. 